\title{
Assessing effects of diel period, gear selectivity and predation on patterns of microhabitat use by fish in a mangrove dominated system in SE Australia
}

\author{
Timothy M. Smith ${ }^{1}$, Jeremy S. Hindell ${ }^{1,2, *}$ \\ ${ }^{1}$ Department of Zoology, University of Melbourne, Parkville, Victoria 3010 Australia \\ ${ }^{2}$ Marine and Freshwater Systems, Department of Primary Industries, PO Box 114, Queenscliff, Victoria 3225, Australia
}

\begin{abstract}
The relative value of temperate mangroves to fish, and the processes driving patterns of microhabitat use within this habitat, are unknown. There are 3 quickly identifiable microhabitats within temperate Australian mangroves: (1) forest (the area of mangroves with trees); (2) pneumatophores (the area directly seaward of the forest without trees but with pneumatophores [aerial roots]); and (3) channel (the area directly seaward of the pneumatophores without gross structural attributes such as trees or pneumatophores). Duplicate fyke and gill nets were both initially used to sample fish in the 3 microhabitats described above. Sampling took place across the seaward edge of mangroves on 10 sampling occasions (5 night and 5 day), in a large estuarine system in SE Australia. Fish assemblages (693 fish from 20 species and 15 families) varied significantly $(p<0.05)$ between the forest and the channel, and between diel periods for each gear (net type), but there was little difference in the assemblage structure of fish between forest-pneumatophore or pneumatophore-channel microhabitats. Juvenile lifestages ( $61 \%$ of all fish) and commercially important taxa ( $76 \%$ ) were common. Abundance, biomass and species richness of fish were generally lower in the forest than the other microhabitats, but this pattern varied significantly $(p<0.05)$ between diel periods, among sampling occasions, and with water depth. Highly quantitative pop nets provided a preliminary assessment of whether differential gear selectivity caused patterns between microhabitats, but less rich fish assemblages were again recorded in forests than in pneumatophores. The importance of predation in structuring fish assemblages across microhabitats was assessed by measuring survival of juvenile fish tethered in 3 predation treatments (predator exclusion, cage control, and uncaged). Survival rates were high across the predator treatments and did not vary among microhabitats. The variation in fish assemblages across microhabitats within mangroves was not consistent with a model of mangrove structure providing a refuge for juvenile fish from predation, but instead could indicate differences in efficiency of gear types among microhabitats and/or other 'edge effect'-driven processes such as the provision of food and/or shelter.
\end{abstract}

KEY WORDS: Temperate · Mangroves · Fish assemblages · Microhabitat · Predation · Diel Resale or republication not permitted without written consent of the publisher

\section{INTRODUCTION}

Mangroves cover significant areas of the intertidal zone of protected bays and inlets throughout the tropics, where they support rich assemblages of algae, invertebrates, birds and fish (Alongi 2002). In the last $50 \mathrm{yr}$, around $50 \%$ of the world's mangroves have been destroyed by, and remain under threat from, human disturbance through urban development, farming, and pollution (Alongi 2002). In Australia, most of our understanding of the value of mangroves to marine fauna, particularly fish, comes from the tropics. We have little understanding of faunal-mangrove associations at temperate latitudes.

High abundances of juvenile fish and invertebrates in mangroves have led to the idea that mangroves are 
a valuable 'nursery' habitat (Robertson \& Duke 1987, Laegdsgaard \& Johnson 1995, Nagelkerken et al. 2001) because they form a source of food and structure that provides a refuge from predators (Bell et al. 1984, Laegdsgaard \& Johnson 2001). Conversely, not all mangroves have been shown to be important habitat (or more important than adjacent habitats) for juvenile and small fishes (Ley et al. 1999, Clynick \& Chapman 2002, Hindell \& Jenkins 2004). Regardless of the pattern, there is little experimental evidence to either support or refute the processes driving alternative patterns (Sheridan \& Hays 2003). Experiments in subtropical Australia showed that juvenile fish (Sillago spp., Liza argentea and Atherinomorus ogilbyi) sought shelter from artificial pneumatophores in the presence of predators, and Sillago spp. were less susceptible to predation and had greater rates of feeding in mangroves than adjacent mudflats (Laegdsgaard \& Johnson 2001). This work was done in subtropical Australia and focussed on between-habitat differences in food and predation, but, given the different structural zones within mangroves (microhabitats), experimental work is needed to assess the role of processes such as predation in structuring fish assemblages between microhabitats within temperate mangroves.

Structural attributes can vary in subtle ways among regions within habitats (microhabitats), leading to small-scale (meters to $10 \mathrm{~s}$ of metres) variability in faunal assemblages (Alevizon et al. 1985, Jernakoff et al. 1996). Mangroves also vary greatly in levels of structural complexity within patches (Ronnback et al. 1999, 2002), often growing in distinct bands at different distances from the waters edge (Underwood \& Chapman 1995, Clarke 2004). These patterns may influence local abundances of epifauna across regions (or microhabitats) within mangrove forests (Satumanatpan et al. 1999, Satumanatpan \& Keough 2001). Despite the apparent delineation of areas within mangroves, most studies have treated them as a single habitat (Hindell \& Jenkins 2004).

The strong patterns in change of structural elements within mangroves, and their potential effects on faunal assemblages, highlights a need for spatially explicit sampling. Most studies, however, have sampled a single region of mangroves, such as channels (Pinto 1987, Chong et al. 1990) and creeks (Bell et al. 1984, Robertson \& Duke 1987, Lin \& Shao 1999), or along edges (Laroche et al. 1997, Hindell \& Jenkins 2004). Additionally, mangrove nekton are commonly sampled with semi-quantitative (measuring abundance but not density), 'passive' methods such as gill and fyke nets, which are efficient methods of sampling nekton but do not measure density. Stake, block and drop nets have been used to provide spatially explicit estimates of fish density (Thayer et al. 1987, Morton 1990, Ley et al.
1999, Lorenz 1999, Ronnback et al. 1999), but more recently bottomless pop nets (hereafter referred to as pop nets) have shown promise in quantifying densities of juvenile fishes within mangroves (Hindell \& Jenkins 2005). To date, few studies have assessed how faunal samples change between highly quantitative and qualitative methods, or discussed the implications for sampling bias in shaping our understanding of small-scale faunal-habitat associations.

Recently, there have been greater efforts to describe patterns of microhabitat use by prawns (Vance et al. 1996, 2002, Ronnback et al. 1999, 2002), barnacles (Satumanatpan et al. 1999, Satumanatpan \& Keough 2001), and crabs (Dahdouh-Guebas et al. 2002) within mangroves. Just 2 studies have investigated microhabitat use by fish within mangroves. Vance et al. (1996) found greater numbers of fish at the mangrove/channel fringe, where the structure in the water column was minimal. Ronnback et al. (1999) found fewer fish at the mangrove fringe and greater numbers deeper in the forest. Both studies found more fish in less structured Avicennia mangroves, smaller individuals inside mangroves than along the fringe, and few piscivorous fish deep in the forest. These patterns were consistent with a model of fish using the interior of mangroves as a refuge from predation, but no experiments were done to test this hypothesis.

Tethering mobile prey is useful in comparing predation rates in different habitats (Aronson et al. 2001, Haywood et al. 2003), particularly in demonstrating the refuge value of mangroves for fish (Laegdsgaard \& Johnson 2001). Tethering, however, may alter an individual's behaviour and escape responses, making it more susceptible to predation (Peterson et al. 2001, Haywood et al. 2003). Prey lost from tethers are generally assumed to be eaten (Acosta \& Butler 1997, Haywood et al. 2003), but predation rates may be overestimated if prey escape their tethers. Laegdsgaard \& Johnson (2001) controlled for this by tethering fish inside cages in each habitat, providing an estimate of fish lost through means other than predation. Future studies comparing survival of tethered prey across habitats of different structure should employ a similar approach to separate predation effects from artefacts of tethering.

Fish-habitat associations often vary between diel periods (Rooker \& Dennis 1991, Gibson et al. 1998, Nagelkerken et al. 2000a). In mangroves, diel migrations by some species are thought to reflect behaviour related to feeding or shelter (Laroche et al. 1997, Nagelkerken et al. 2000a). In the only study on diel fish variations in temperate mangroves, Clynick \& Chapman (2002) found no difference in fish abundance and species richness between day and night samples. Different microhabitats within mangroves provide vary- 
ing levels of food and shelter for fish (Ronnback et al. 1999), and while these patterns may facilitate strong differences in assemblages of fish across microhabitats between times of the day, no study has attempted to explore this relationship.

To increase our understanding of the role of temperate mangroves in supporting assemblages of fish, the present study aimed to (1) quantify abundances of fishes using mangroves in temperate Australia; (2) assess whether fish assemblages varied across mangrove microhabitats between diel periods; (3) measure the consistency in fish samples between quantitative and qualitative sampling methods; and (4) determine the importance of predation in shaping microhabitat use by fish within mangroves.

\section{MATERIALS AND METHODS}

Study site. This study was done in the Barwon River Estuary, Victoria, Australia (Fig. 1), between September 2003 and April 2004. The estuary is tidally dominated, with semi-diurnal tides that range in height between 1 and $1.7 \mathrm{~m}$ above mean low water (OZESTUARIES 2000). Natural vegetation in the catchment has been largely cleared for urbanisation, but a single species of mangrove, Avicennia marina (Forsskal) Vierhapper, covers large areas of the intertidal mudflat. The remaining intertidal region is largely unvegetated mud flat with a sparse covering of seagrass (Zosteraceae: Zostera muelleri, Irmisch ex Ascherson). The stands of $A$. marina are typical of those elsewhere in Victoria's bays and inlets; trees are stunted in growth $(<3 \mathrm{~m}$ in height) and distributed in small discontinuous stands (Harty 1997). Victoria's mangroves generally lack the small but deep channels draining mangrove forests in tropical systems, and nekton associated with mangroves must therefore be sampled directly from the forest rather than tidal creeks and rivulets draining the intertidal flats. The mangroves are inundated each high tide, but the length of time and depth of inundation depends on tidal regimes and local climatic conditions. During lowpressure weather patterns and large coastal swells, the water level and mean tidal range inside Victoria's bays and inlets increases (Jenkins \& Black 1994).

The mangrove 'habitat' in our study area can be divided into 3 microhabitat types based on gross structural attributes: forest, pneumatophores, and channel. The forest is dominated by mangrove trees and dense pneumatophores (aerial roots of mangroves, mean length $\pm \mathrm{SE}=19.4 \pm 5.4 \mathrm{~cm}$, mean density $\pm \mathrm{SE}=78.8 \pm 7.4 \mathrm{~m}^{-2}$ ), and occurs in narrow bands $\sim 10$ to 20 m seaward from the top of the intertidal. The pneumatophore microhabitat lacks mangrove trees but has many pneumatophores, which are similar in length (mean $\pm \mathrm{SE}=16.0 \pm 2.1 \mathrm{~cm}$ ) but less dense (mean $\pm \mathrm{SE}=38.4 \pm 4.0 \mathrm{~m}^{-2}$ ) than in the forest. Pneumatophores inside and outside the forest support a variety of algal (e.g. Ulva spp., Enteromorpha spp., Caloglossa spp. and Cantenella spp.) and molluscan/ crustacean taxa (e.g. Eliminius modestus, Austrocochlea constricta, and Bembicium auratum). The channel microhabitat is defined by the absence of pneumatophores and trees, and is the area immediately seaward (to $10 \mathrm{~m}$ ) of the pneumatophore microhabitat.

Survey 1: variability in fish assemblages among microhabitats and between diel periods. To assess whether assemblages of fish varied among microhabitats within mangroves (forest, pneumatophore, channel) and between diel periods, fish in each microhabitat were sampled both day and night on 5 separate occasions. Sampling times were chosen in correspon-

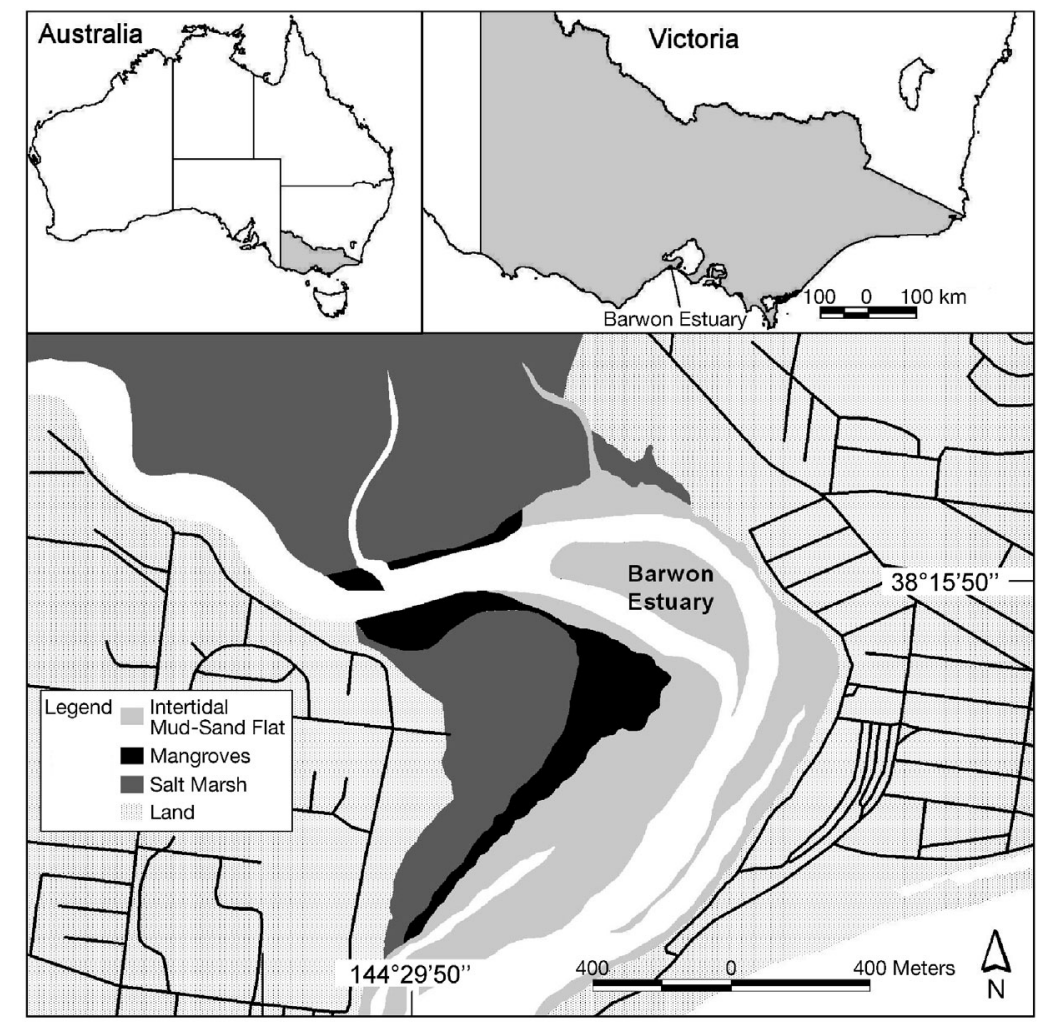

Fig. 1. Location of the study area in the Barwon River. Inset: location of the Barwon River in Australia. Sampling was done in and around the mangrove habitat (shown in black) throughout the study area 
dence with spring tides to ensure that mangrove forests were flooded (Hindell \& Jenkins 2004). On each sampling occasion (day or night), fish in each of the microhabitats were sampled with replicate $(n=2)$ fyke and gill nets (i.e. 6 fyke and 6 gill nets were set, 2 in each microhabitat). Care was taken to ensure nets of the same net type were not set alongside one another within or among microhabitats. Fishing times of each net were recorded for each sampling event.

Fyke nets are a common method of sampling fish associated with mangroves, and are particularly useful in targeting small fish (Lin \& Shao 1999, Clynick \& Chapman 2002). The fyke nets used here are well described in Hindell \& Jenkins (2004). Briefly, nets were made from four $0.7 \times 0.7 \mathrm{~m}$ aluminum frames, around which $6 \mathrm{~mm}$ black honeycomb mesh was attached. A $6 \times 0.7 \mathrm{~m}$ length of the same mesh (wing) was attached to each side of the net opening. Floats and a lead line were attached to the top and bottom of the wings, respectively. Fyke nets were set so that the opening (and wings) faced landward in each microhabitat. Fyke nets were set and retrieved approximately 2 to $3 \mathrm{~h}$ before and after mean high water. The maximum water depth at each fyke net was recorded so that we could further assess how water depth variability in each microhabitat influenced fish assemblages. Fyke nets were set and collected on foot, taking care not to disturb surrounding pneumatophores.

Gill nets are efficient methods of sampling transient species with a variety of morphologies, particularly larger (>15 cm total length) fishes (Hindell et al. 2000). The gill nets used here are described in detail by Hindell \& Jenkins (2004). Briefly, nets were comprised of five $7 \times 1.5 \mathrm{~m}$ long panels of mesh, each of a different size $(2.5,3.8,5.0,6.3,7.6 \mathrm{~cm}$ stretch mesh), joined to make a $35 \mathrm{~m}$ long net. The different mesh sizes enabled us to target fish of different sizes because there is a high degree of size-selectivity for specific mesh sizes (Acosta \& Appeldoorn 1995, Gray 2002). Floats and a lead-line were attached to the top and bottom, respectively, and two $3 \mathrm{~kg}$ weights were attached to each end to prevent the nets from moving with the currents. Gill nets were set along the centre line of each microhabitat, parallel to the landward margin of the shoreline $\sim 2 \mathrm{~h}$ before, and collected $\sim 2 \mathrm{~h}$ after high tide. Gill nets were set and retrieved from a boat or on foot depending on the water depth.

Where possible, all fish were returned alive to the water after the species were identified (Gomon et al. 1994), and their weight (g) and length (SL: from the tip of the snout to the posterior end of the caudal peduncle, mm) were measured. If this was not possible, fish were anaesthetised and preserved in $90 \%$ ethanol.
Survey 2: fyke versus pop nets in mangroves. Gear (net type) selectivity can vary with habitat and water depth (Rozas \& Minello 1997). It was possible that patterns observed in fish assemblages between microhabitats in the present study could reflect sampling efficiency. To assess whether differences in fish assemblages sampled with gill and fyke nets among microhabitats were 'real' or due to sampling bias, fyke and pop nets were used to sample fish on 5 additional occasions during the day. On each occasion, a single fyke and pop net was set in each of the forest and pneumatophore microhabitats. No nets were set in the channel because water depth and currents were unsuitable for sampling with pop nets. Survey 2 was done directly after completing Survey 1 so that we could better compare the findings from the 2 surveys.

Pop nets are a highly quantitative method of sampling fish in intertidal habitats with high levels of structure (Rozas 1992, Connolly 1994). The operation and design of pop nets is well described by Connolly (1994) and Hindell \& Jenkins (2005). Briefly, each net had $5 \times 5 \mathrm{~m}$ buoyant and weighted frames made from $20 \mathrm{~mm}$ PVC pipe. Silicone sealant was used to seal air inside the buoyant frame. Steel rods $(10 \mathrm{~mm}$ diameter $\times 4 \mathrm{~m}$ ) were placed inside the weighted frame. The buoyant and weighted frames were attached to the top and bottom, respectively, of a net $(20 \mathrm{~m}$ long $\times 1.2 \mathrm{~m}$ high, $1 \mathrm{~mm}$ mesh and a zip at one end to allow the net to be formed into an enclosure). With the top and bottom frames together (and the net in between) the pop nets were gradually pushed into the substratum until the top of the net was level with the surface, thereby reducing the need for a trench to be dug. A release mechanism, consisting of a $20 \mathrm{~kg}$ monofilament line attached to plastic clamps at 3 positions along each side of the net, was attached to each pop net so that they could be set off remotely. For each pair of opposing sides, lines were run to a single point $\sim 30 \mathrm{~m}$ away, which was marked with a buoy so that it could be found at high tide. At high tide, 2 people (1 at each buoy) retrieved the steel pegs with lines attached and simultaneously pulled the monofilament lines to release the buoyant frame, which rose to the surface in 1 to $2 \mathrm{~s}$. Nets were monitored to prevent predation by birds on fish, and when the tide had receded, trapped fish were collected by hand, anaesthetised and preserved as above.

Predation across microhabitats within mangroves. Variation in predation pressure at different positions within mangroves is thought to explain changes in fish assemblages across microhabitats (Vance et al. 1996, Ronnback et al. 1999). To determine if predation varied across microhabitats within mangroves, the survival (fish remaining tethered) of juvenile Aldrichetta forsteri (Mugilidae) Valenciennes was measured in the 
forest, pneumatophore, and channel, with and without pressure from predation.

On each of 5 separate daytime sampling occasions, 3 juvenile ( $<10 \mathrm{~cm}$ SL) Aldrichetta forsteri were tethered in each of 3 predation treatments (predator exclusion cage, cage control, no cage) in each microhabitat. Predator exclusion cages provided a means of assessing whether fish were missing from tethers through means other than predation. Cage controls assessed whether differences in survival between caged and uncaged areas were due to the structure of the cage. Uncaged treatments assessed 'natural' predation levels in each microhabitat. Each cage was constructed from a $1 \times 1 \times 0.3 \mathrm{~m}$ wooden frame enclosed by $1 \mathrm{~cm}$ green plastic mesh. This mesh size excludes fish preying on juvenile mugilids (Hindell et al. 2001). A $5 \mathrm{~cm}$ steel sheet was attached to the bottom of each cage so that it could be secured in the substratum. Cage controls were made from the same materials as exclusion cages but had $0.5 \times 0.2 \mathrm{~m}$ holes cut in each side to allow predatory fish entry. A. forsteri were tethered to clips and attached to monofilament line (see below) that stretched between steel stakes attached to the cages (exclusions and controls) at opposing corners. Fish in the uncaged treatments were tethered to the same length of monofilament line stretched between 2 steel stakes.

The 'predatory' and 'prey' species highlighted in the current study were based on stomach content analyses of fish by Robertson (1982), Edgar \& Shaw (1995) and Hindell et al. (2000). The western Australian salmon Arripis truttacea, Cuvier, in particular, are voracious predators on juvenile and small fish from a wide variety of species including mugilids, and are often among the most abundant fishes in shallow estuarine habitats during the day (Robertson 1982, Edgar \& Shaw 1995, Hindell et al. 2000, current study).

Juvenile Aldrichetta forsteri were chosen as prey for 3 reasons: (1) they are common throughout the study system and are among the most common species sampled in temperate Australian mangroves (Hindell \& Jenkins 2004); (2) they are a common prey species for predatory fishes such as Arripis truttacea and Acanthopagrus butcheri (Sparidae) Munro (Hindell et al. 2000); and (3) they are easy to tether, robust, and tolerant to handling. On each occasion, A. forsteri were collected $<2 \mathrm{~h}$ before tethering with a $6 \times 1.5 \mathrm{~m}, 10 \mathrm{~mm}$ seine net from nearby mudflats. Each fish was attached to a $15 \mathrm{~cm}$ length of $5 \mathrm{~kg}$ monofilament line, which was tied to the bottom jaw of the fish at one end and to a small clip at the other. When water depth in the forest reached $\sim 20 \mathrm{~cm}$, fish were tethered in each cage treatment, in each microhabitat ( $\mathrm{n}=27$ fish on each sampling occasion). The standard length of each fish was measured prior to tethering to ensure that similarly sized fish were used in each treatment. The numbers of fish remaining in each treatment after $\sim 2 \mathrm{~h}$ (time of forest inundation) were recorded.

Data analysis. Univariate analysis: All data were checked for normality and homogeneity of variance using box plots and plots of residuals (Quinn \& Keough 2002). Where data did not meet these assumptions, they were transformed ( $\log _{10}$ or arcsine) and reassessed. Fish abundances were always adjusted for time (fyke and gill nets) or area (pop nets) fished. Survival of tethered fish was adjusted by time of tethering.

In Survey 1, variability in abundances, biomass and species richness (the number of species) between diel periods, and among sampling occasions and microhabitats was analysed using 3-factor partially nested analyses of variance (ANOVAs). Microhabitat (forest, pneumatophores, channel) and diel period (day, night) were treated as fixed factors, sampling occasion was treated as a random factor nested within diel period, and nets (fyke, gill) were analysed separately. The relationships between total species richness and abundance, pooled across diel periods and gear, and water depth were analysed using regression analyses. In the second survey, 2-factor randomised blocks ANOVAs were used to assess variability in fish abundances between microhabitats (fixed factor: pneumatophore, forest) and sampling occasions (random factor, 1 to 5) for each gear separately (fyke vs. pop nets). Tukey's tests were used to assess the degree to which dependent variables differed between levels of independent factors for both sets of analyses. In the predation experiment, variability in survival of juvenile fish between microhabitats and caging treatments (closed cage, open cage, no cage) was analysed with a 3-factor randomised blocks ANOVA. Non-significant ( $p<0.05$ ) differences among microhabitats and caging treatments were assessed with post hoc power analyses. An effect size (ES) of $66 \%$ was chosen to correspond with the loss of 2 fish from an experimental cage. Power analyses were done using GPower (Faul \& Erdfelder 1992). All univariate analyses were done using SYSTAT (Wilkinson et al. 1992).

Multivariate analysis: Multidimensional scaling (MDS), analysis of similarity (ANOSIM) and similarity percentages (SIMPER), based on Bray-Curtis dissimilarity indices calculated from fish abundances, were used to assess whether fish assemblages varied (1) among microhabitats and between diel periods (survey 1), and (2) between gear types and microhabitats (Survey 2). In Survey 1, analyses were first run on raw (non-transformed) data. The same analyses were then run on transformed $(\log [x+1])$ data, and if the results were the same regardless of whether the data had been transformed, then the results from the analyses of raw data were used (as was the case in this study). In 
Survey 2, data were transformed to presence/absence because even though the gear used (fyke and pop nets) provided very different estimates of abundance (fykefish $\mathrm{h}^{-1}$, pop-fish $\mathrm{m}^{-2}$ ), we still wanted to assess whether the overall assemblage structure differed between gear types. Sampling occasions when no fish were sampled were removed from analyses. Multivariate analyses were done using PRIMER (Clarke \& Warwick 2001).

\section{RESULTS}

\section{Variability in fish assemblages among microhabitats and between diel periods (Survey 1)}

A total of 693 fish (20 spp. from 15 families) were sampled over 10 sampling occasions (5 day, 5 night; Table 1). Arripis truttacea and Aldrichetta forsteri constituted $63 \%$ of all fish, while 6 species - brown trout Salmo trutta, Linnaeus, tailor Pomatomus saltatrix, Linnaeus), tommy ruff Arripis georgiana, Valenciennes, sea mullet Myxus elongates, Gunther, cod larvae Pseudophycis spp. and long snout flounder (Ammo- tretis rostratus, Gunther) were sampled only once (Table 1). Marine species represented $74 \%$ of all fish, freshwater and estuarine species accounted for $13 \%$, and 12 species (76\% by abundance) were of commercial importance (Kailola et al. 1993). Based on size ranges in Gomon et al. (1994), 61 \% were juveniles. Gill nets sampled 450 fish, mostly >100 mm SL, such as Acanthopagrus butcheri, white trevally Pseudocaranx dentex, Bloch and Schneider, and A. truttacea. Fyke nets were more successful at sampling fishes $<100 \mathrm{~mm}$ SL, such as the common jollytail Galaxias maculatus, Jenyns, bridled goby Arenigobius bifrenatus, Kner, and Tamar river goby Favonigobius tamarensis, Johnston.

The fish assemblages sampled with fyke and gill nets varied strongly between diel periods and among microhabitats (Table 2, Fig. 2). For both gear types, the variability in fish assemblages among microhabitats was driven most by differences between the forest and the channel (Table 2, Fig. 2). The diel differences in assemblage structure for fishes sampled with the fyke nets were driven primarily by Favonigobius tamarensis (21\%), Galaxias maculatus (20\%) and Aldrichetta forsteri $(17 \%)$, while F. tamarensis $(27 \%)$, Tetractenos

Table 1. Summary of fish sampled in (1) Survey 1 among microhabitats (channel: Ch, pneumatophores: Pn, and forest: F) during each diel period (day, night) pooled across gear type; and (2) Survey 2 among microhabitats using pop and fyke nets. $\mathrm{n}=$ number, $\mathrm{W}=$ weight $(\mathrm{g})$, SL $=$ average length (mm). Values rounded to whole numbers

\begin{tabular}{|c|c|c|c|c|c|c|c|c|c|c|c|c|c|c|c|c|c|c|c|c|c|c|}
\hline & \multicolumn{18}{|c|}{ - Survey 1} & \multirow{2}{*}{\multicolumn{4}{|c|}{$\begin{array}{l}\text { - Survey } 2 \\
\text { —Pop_-Fyke- }\end{array}$}} \\
\hline & \multirow{2}{*}{\multicolumn{3}{|c|}{$\mathrm{Ch}$}} & \multirow{2}{*}{\multicolumn{3}{|c|}{ - Day- }} & \multirow{2}{*}{\multicolumn{3}{|c|}{$\mathrm{F}$}} & & & & $-\mathrm{N}$ & Night & & & & & & & & \\
\hline & & & & & & & & & & \multicolumn{3}{|c|}{$\mathrm{Ch}$} & \multicolumn{3}{|c|}{$\mathrm{Pn}$} & \multicolumn{3}{|c|}{$\mathrm{F}$} & \multirow{2}{*}{$\begin{array}{l}\mathrm{Pn} \\
\mathrm{n}\end{array}$} & \multirow{2}{*}{$\mathrm{F}$} & \multirow{2}{*}{$\begin{array}{l}\mathrm{Pn} \\
\mathrm{n}\end{array}$} & \multirow{2}{*}{$\begin{array}{l}\mathrm{F} \\
\mathrm{n}\end{array}$} \\
\hline & $\mathrm{n}$ & W & SL & $\mathrm{n}$ & W & SL & $\mathrm{n}$ & W & SL & $\mathrm{n}$ & W & SL & $\mathrm{n}$ & W & SL & $\mathrm{n}$ & W & $\mathrm{SL}$ & & & & \\
\hline Anguilla australis ${ }^{\mathrm{C}, \mathrm{J}}, \mathrm{A}$ & & & & & & & & & & 11 & 4751 & 526 & 17 & 75129 & 464 & 1 & 280 & 380 & & & & 1 \\
\hline Arripis georgiana ${ }^{\mathrm{C}, \mathrm{J}}$ & & & & & & & & & & & & & 1 & 1 & & & & & & & & \\
\hline Arripis truttacea $\mathrm{C}, \mathrm{J}$ & 98 & 4479 & 133 & 2 & 19 & 83 & & & & 80 & 6523 & 156 & 57 & 74472 & 154 & & & & 2 & & 1 & \\
\hline Atherinasoma microstoma ${ }^{\mathrm{J}, \mathrm{A}}$ & & & & & & & 1 & ** & 25 & 1 & ** & 23 & 2 & 1 & 46 & & & & 89 & 21 & 916 & 23 \\
\hline Pseudocaranx dentex ${ }^{\mathrm{C}, \mathrm{J}, \mathrm{A}}$ & 2 & 87 & 125 & & & & & & & 14 & 1074 & 135 & 2 & 89 & 128 & & & & & & & \\
\hline Hyperlophus vittatus $^{\mathrm{C}, \mathrm{J}}$ & & & & & & & & & & & & & & & & & & & & & 65 & \\
\hline Engraulis australis ${ }^{\mathrm{C}, \mathrm{A}}$ & & & & & & & & & & & & & & & & & & & & & 1 & \\
\hline Galaxias maculatus ${ }^{\mathrm{J}}$ & 13 & 1 & 36 & 15 & 2 & 36 & 1 & ** & 44 & 13 & 2 & 36 & 16 & 3 & 35 & 3 & ** 4 & 45 & & & & 2 \\
\hline Girella tricuspidata ${ }^{\mathrm{C}} \mathrm{A}$ & & & & & & & & & & & & & 2 & 23610 & 377 & & & & & & & \\
\hline Arenigobius bifrenatus ${ }^{\mathrm{A}}$ & 1 & & & & & & & & & 9 & & & 2 & 2 & & & & & & & & \\
\hline Favonigobius tamarensis $^{\mathrm{A}}$ & 38 & 41 & 42 & 2 & 5 & 57 & & & & 12 & 22 & 51 & 3 & 6 & 49 & & & & 10 & & & \\
\hline Pseudophycis sp. ${ }^{J}$ & & & & 1 & ** & 21 & & & & & & & & & & & & & & & & \\
\hline Aldrichetta forsteri $\mathrm{C}, \mathrm{J}, \mathrm{A}$ & 63 & 3097 & 144 & 18 & 507 & 119 & & & & 51 & 3637 & 161 & 57 & 73452 & 152 & 13 & 603 & 3130 & 1 & & 100 & \\
\hline Mugil cephalus ${ }^{\mathrm{C}, \mathrm{J}}$ & 1 & 119 & 180 & & & & & & & & & & & & & & & & & & & \\
\hline Ammotretis rostratus ${ }^{\mathrm{A}}$ & & & & & & & & & & & & & 1 & 3 & 54 & & & & 1 & & & \\
\hline Rhombosolea tapirina $^{\mathrm{C}, \mathrm{J}, \mathrm{A}}$ & 2 & 111 & 100 & & & & & & & & & & & & & & & & & & & \\
\hline Pomatomus saltatrix ${ }^{\mathrm{C}, \mathrm{J}}$ & 1 & 63 & 158 & & & & & & & & & & & & & & & & & & & \\
\hline Salmo trutta ${ }^{\mathrm{C}, \mathrm{J}}$ & 1 & 127 & 212 & & & & & & & & & & & & & & & & & & & \\
\hline Gymnapistes marmoratus ${ }^{\mathrm{A}}$ & 2 & 59 & 102 & & & & & & & & & & & & & & & & & & & \\
\hline Sillaginodes punctata ${ }^{\mathrm{C}, \mathrm{J}}$ & 9 & 178 & 130 & 2 & 46 & & & & & 3 & 127 & 154 & 3 & 3125 & 164 & & & & 1 & & & \\
\hline Acanthopagrus butcheri ${ }^{\mathrm{C}, \mathrm{J}} \mathrm{A}$ & A 1 & 460 & 234 & & & & & & & 7 & 3203 & 227 & 6 & 62848 & 214 & 3 & 1622 & 280 & & & & \\
\hline Stigmatopora nigra ${ }^{\mathrm{A}}$ & & & & & & & & & & & & & & & & & & & 1 & & & \\
\hline Tetractenos glaber ${ }^{\mathrm{J}, \mathrm{A}}$ & 14 & 964 & 109 & 10 & 700 & 106 & 2 & 149 & 110 & 2 & 137 & 119 & 1 & 93 & 130 & & & & 3 & 2 & 19 & 2 \\
\hline Average & & 39 & 131 & & 25 & 70 & & 37 & 59 & & 95 & 159 & & 116 & 164 & & 125 & & & & & \\
\hline Total & 246 & & & 50 & & & 4 & & & 203 & & & 170 & & & 20 & & & 108 & 23 & 1102 & 28 \\
\hline
\end{tabular}




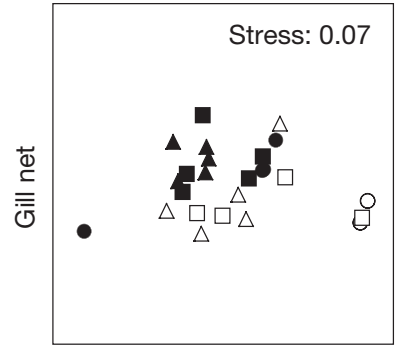

Night $\quad \Delta$ Channel

Day $\triangle$ Channel

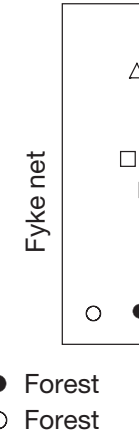

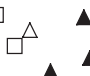

$\Delta \Delta$

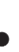

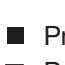

Pneumatophores

Pneumatophores
Stress: 0.14

Fig. 2. Multidimensional scaling plots, based on Bray-Curtis dissimilarity indices calculated from fish abundances, comparing microhabitats (channel, pneumatophores, and forest) and diel periods (day, night) for each gear type (gill, fyke) separately. Two night-forest and 3 day-forest points are superimposed for both net types. Two day pneumatophore fyke net and 1 day pneumatophore gill net points are superimposed. Total $\mathrm{n}=30$

glaber $(17 \%)$ and G. maculatus $(16 \%)$ contributed most to assemblage differences between the forest and channel. For the gill net sampled fishes, Arripis truttacea $(36 \%)$ and A. forsteri (35\%) contributed most to diel differences and differences between the forest and channel (A. truttacea $41 \%$, A. forsteri $29 \%$ ).

Table 2. Summary of multivariate analyses of similarity comparing fish assemblages among microhabitats (forest, pneumatophore, and channel), and between diel periods (day, night) for each gear type (gill, fyke) separately. Total $\mathrm{n}=30$. Bold indicates $\mathrm{p}<0.05$

\begin{tabular}{|lcccc|}
\hline \multirow{2}{*}{ Source } & \multicolumn{2}{c}{ Gill net } & \multicolumn{2}{c|}{ Fyke net } \\
& Global R & $\mathrm{p}$ & Global R & $\mathrm{p}$ \\
\hline Diel & 0.276 & $\mathbf{0 . 0 0 6}$ & 0.424 & $\mathbf{0 . 0 0 1}$ \\
Microhabitat & 0.261 & $\mathbf{0 . 0 1 0}$ & 0.196 & $\mathbf{0 . 0 3 7}$ \\
Forest vs. pneumatophore & 0.135 & 0.139 & 0.287 & 0.061 \\
Forest vs. channel & 0.798 & $\mathbf{0 . 0 0 1}$ & 0.46 & $\mathbf{0 . 0 0 4}$ \\
Pneumatophore vs. channel & -0.04 & 0.625 & -0.034 & 0.551 \\
& & & & \\
\hline
\end{tabular}

Fish abundances in fyke and gill nets varied inconsistently among microhabitats between sampling occasions and diel periods (Table 3, Fig. 3). Tukey's tests showed that fish were statistically more abundant $(\mathrm{p}<$ 0.05 ) in the channel than in the pneumatophore (on 3 occasions, 1 day and 2 nights, Fig. 3) and forest (on 8 occasions, 4 days and 4 nights, Fig. 3 ) regions when sampled with gill nets. On 3 night occasions more fish were sampled in the pneumatophores than the forest. Fish abundances in the fyke nets were significantly greater in the channel than in the pneumatophores on 2 night and 3 day occasions, significantly greater in the channel than the forest on 6 occasions (3 day, 3 night, Fig. 3), and significantly greater in the pneumatophores than the forest on 6 occasions (2 day, 4 night, Fig. 3). There was a significant positive relationship between fish abundance and water depth in the pneumatophores and forest, but not in the channel (Table 4). The mean $( \pm \mathrm{SE})$ water depths $(\mathrm{cm})$ in the forest, pneumatophore and channel were $49( \pm 7), 66( \pm 9)$ and $90( \pm 7)$, respectively.

Fish biomass varied significantly among microhabitats between diel periods for both gill and fyke nets (Table 3 , Fig. 4). Tukey's tests (statistically significant at $p<0.05$ ) showed that fish biomass in gill nets was greater in the channel than in the pneumatophores, which had greater biomass than the forest (Fig. 4). Fish biomass in the gill nets was also greater during the night than during day periods (Fig. 4). In the fyke nets biomass was greater in the channel and pneumatophore habitats than in the forest, but was similar between the channel and pneumatophores (Fig. 4). Fish biomass was greater during the night than day for both gear types (Fig. 4).

Species richness in the gill nets varied inconsistently among sampling occasions, microhabitats, and between diel periods; but in the fyke nets it only

Table 3. Results of 3-factor partially nested analyses of variance comparing fish abundance, biomass and species richness among microhabitats (forest, pneumatophore, and channel), and sampling occasions (1 to 10) nested within diel periods (night, day) for each gear type (fyke, gill) separately. Data is $\log _{10}$-transformed. Total $n=120$. Bold indicates $\mathrm{p}<0.05$

\begin{tabular}{|c|c|c|c|c|c|c|c|c|c|c|c|c|c|}
\hline \multirow[t]{3}{*}{ Source } & \multirow[b]{3}{*}{ df } & \multicolumn{4}{|c|}{ Abundance - } & \multicolumn{4}{|c|}{ _ Biomass } & \multicolumn{4}{|c|}{ Species richness } \\
\hline & & \multicolumn{2}{|c|}{ Gill } & \multicolumn{2}{|c|}{ Fyke } & \multicolumn{2}{|c|}{ Gill } & \multicolumn{2}{|c|}{ Fyke } & \multicolumn{2}{|c|}{ Gill } & \multicolumn{2}{|c|}{ Fyke } \\
\hline & & MS & $\mathrm{p}$ & MS & $\mathrm{p}$ & MS & $\mathrm{p}$ & MS & $\mathrm{p}$ & MS & $\mathrm{p}$ & MS & $\mathrm{p}$ \\
\hline Diel (D) & 1 & 1.429 & 0.108 & 0.650 & 0.042 & 45.730 & 0.003 & 29.349 & 0.003 & 0.335 & 0.076 & 0.477 & 0.007 \\
\hline Microhabitat (M) & 2 & 8.459 & $<0.000$ & 3.441 & $<0.000$ & 72.145 & $<0.000$ & 52.586 & $<0.000$ & 1.447 & $<0.000$ & 0.812 & $<0.000$ \\
\hline $\mathrm{D} \times \mathrm{M}$ & 2 & 0.639 & 0.265 & 0.433 & 0.226 & 5.290 & 0.258 & 4.247 & 0.281 & 0.086 & 0.015 & 0.083 & 0.228 \\
\hline Occasion $\{D\}$ & 8 & 0.437 & 0.022 & 0.111 & 0.524 & 2.462 & 0.555 & 1.661 & 0.519 & 0.081 & 0.006 & 0.035 & 0.056 \\
\hline$M \times$ Occasion $\{D\}$ & 16 & 0.443 & 0.008 & 0.265 & 0.029 & 3.583 & 0.283 & 3.086 & 0.103 & 0.015 & 0.797 & 0.051 & 0.003 \\
\hline Error & 30 & 0.161 & & 0.122 & & 2.843 & & 1.819 & & 0.023 & & 0.016 & \\
\hline
\end{tabular}




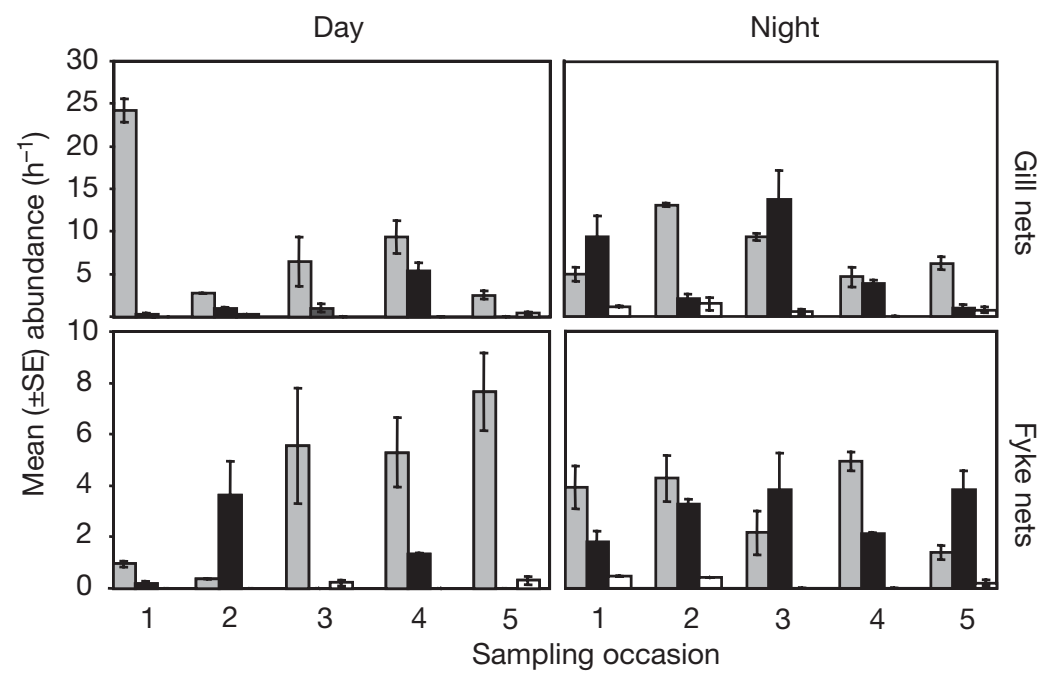

Fig. 3. Mean $( \pm \mathrm{SE})$ abundance of fish sampled in gill and fyke nets $\left(\mathrm{h}^{-1}\right)$ during diel cycles (day, night) in each microhabitat ( $\square$ channel, $\square$ pneumatophores, $\square$ forest) for each sampling occasion. Total $n=120$

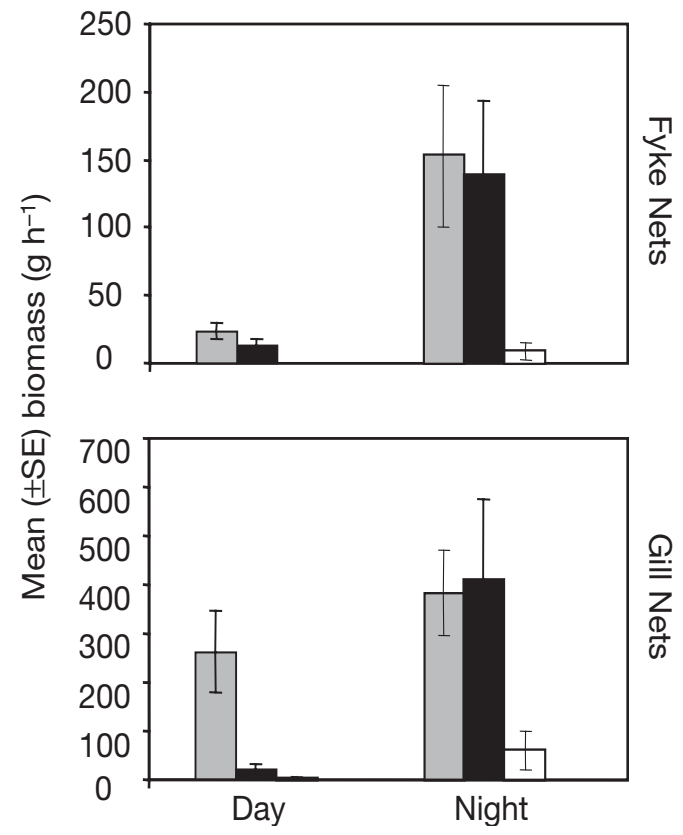

Fig. 4. Mean $( \pm \mathrm{SE})$ biomass of fish sampled in gill and fyke nets $\left(\mathrm{h}^{-1}\right)$ during diel cycles (day, night) in each microhabitat

( $\square$ channel, $\square$ pneumatophores, $\square$ forest). Total $n=120$ varied among microhabitats through time (Table 3, Fig. 5). Using Tukey's tests (as above), species richness measured with gill nets was generally lower in the forest than in the pneumatophores and channel, regardless of diel period. However, differences between the pneumatophores and channel depended on the time of day, during day periods species richness was lower in the pneumatophores than in the channel, while at night, species richness was similar among microhabitats. Like gill net samples, species richness in the fyke nets was often significantly lower in the forest than in the pneumatophores (1 day, 3 nights), and channel (3 days, 3 nights). On most sampling occasions, however, there was little difference between the pneumatophores and the channel (Fig. 5). There were no significant relationships between species richness and water depth in any of the microhabitats (Table 4).

Fyke versus pop nets in the mangroves (Survey 2)

Patterns in the fish assemblages across microhabitats (forest and pneumatophores) were similar for each type of gear (pop and fyke nets). Although only based on 5 replicates in each microhabitat, ANOSIM showed no difference in the species composition (based on presence/absence) sampled in the pop and fyke nets $(\mathrm{R}=-0.026, \mathrm{p}=0.544)$. Notwithstanding similarity in the assemblages, each gear type sampled slightly different numbers of fish among microhabitats. Pop nets sampled 23 fish from 2 species (Atherinasoma microstoma and Tetractenos glaber) in the forest, and 108 fish from 8 species in the pneumatophores (Table 1). Fyke nets sampled similar numbers $(\mathrm{n}=28)$ of fish to the pop nets in the forest (Table 1, Fig. 6), but 10 times more fish $(\mathrm{n}=1102)$ in the pneumatophores. A. microstoma dominated catches in both net types (>80\%) in the pneumatophores (Table 1). Abundances of fish were greater (albeit weakly non-significant) in the pneumatophores

Table 4. Regression analyses of the relationships between fish abundance/species richness and depth, regardless of gear type or diel period, in each microhabitat. Trend indicates the overall pattern of the relationship. Abundance data is $\log _{10}$ $(x+1)$-transformed. Total $\mathrm{n}=10$. Bold indicates $\mathrm{p}<0.05$

\begin{tabular}{|c|c|c|c|c|c|c|c|c|c|c|c|c|c|}
\hline & \multirow[b]{2}{*}{$\mathrm{df}$} & \multicolumn{4}{|c|}{ _Channel } & \multicolumn{4}{|c|}{ _ Pneumatophores } & \multicolumn{4}{|c|}{-Forest } \\
\hline & & $\mathrm{R}^{2}$ & MS & $\mathrm{p}$ & Trend & $\mathrm{R}^{2}$ & MS & $\mathrm{p}$ & Trend & $\mathrm{R}^{2}$ & MS & $\mathrm{p}$ & Trend \\
\hline Abundance & 1,8 & 0.117 & 0.266 & 0.332 & - & 0.438 & 3.436 & 0.037 & + & 0.579 & 0.798 & 0.011 & + \\
\hline Species richness & 1,8 & 0.117 & 0.119 & 0.332 & + & 0.267 & 0.732 & 0.126 & + & 0.371 & 0.201 & 0.062 & + \\
\hline
\end{tabular}




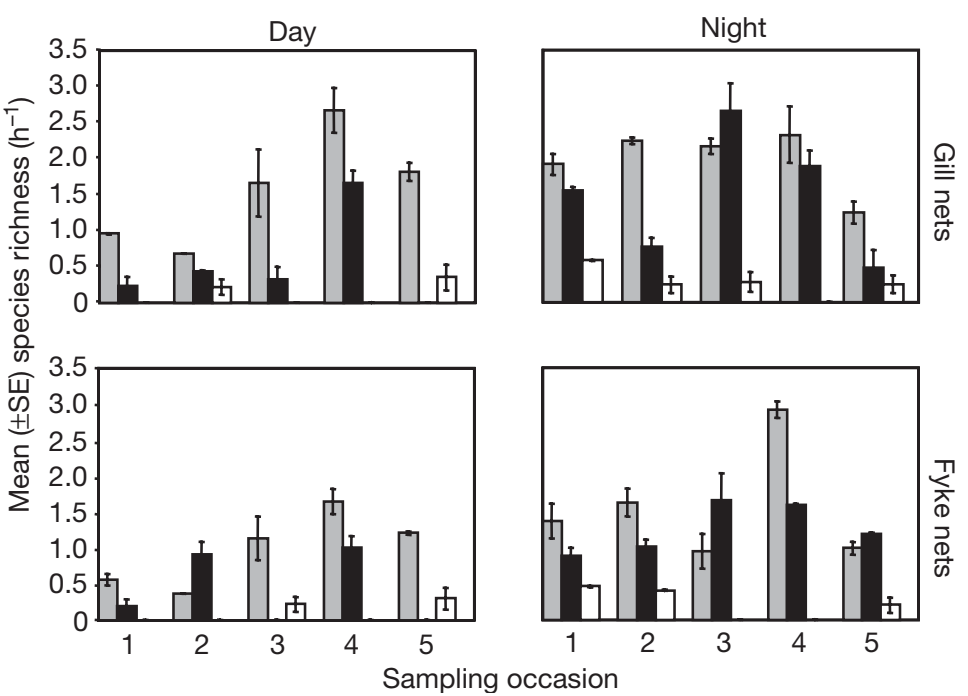

Fig. 5. Mean $( \pm \mathrm{SE})$ species richness sampled in gill and fyke nets $\left(\mathrm{h}^{-1}\right)$ during diel cycles (day, night) in each microhabitat ( $\square$ channel, - pneumatophores, $\square$ forest) for each sampling occasion. Total $\mathrm{n}=120$
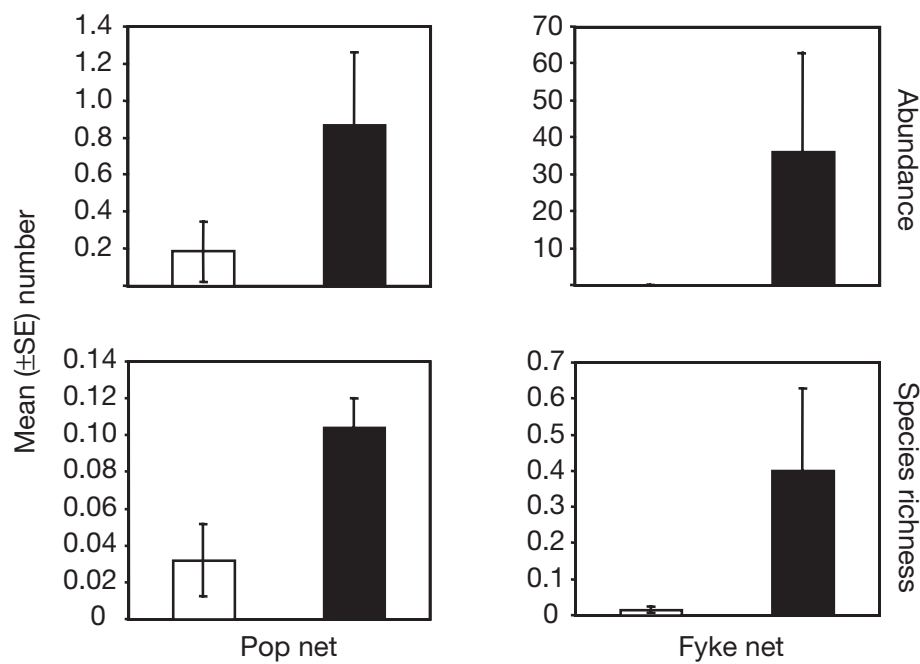

Fig. 6. Mean $( \pm \mathrm{SE})$ abundance and species richness of fish sampled with the pop $\left(\mathrm{m}^{-2}\right)$ and fyke $\left(\mathrm{h}^{-1}\right)$ nets in the forest $(\square)$ and pneumatophore $(\mathbb{\square})$ regions. Total $\mathrm{n}=20$ than forest for both types of gear (Table 5, Fig. 6). Species richness was also greater in the pneumatophores than in the forest for both gear types, but significantly so only for the pop nets (Table 5, Fig. 6). Neither fish abundances nor species richness varied significantly among sampling occasions (Table 5).

\section{Predation across microhabitats within mangroves}

The survival of juvenile Aldrichetta forsteri did not vary significantly among microhabitats or cage treatments (Table 6, Fig. 7). Of 135 fish tethered, only 15 were 'lost' (Fig. 7), 5, 4 and 6 fish in the channel, pneumatophores and forest, respectively. Most $(\mathrm{n}=9)$ fish were lost from uncaged plots, 2 from exclusion cages, and 4 from cage controls. The proportion of fish surviving did not vary significantly among microhabitats or caging treatments (Table 6, Fig. 7).

The lack of significant microhabitat or predator treatment effects was not simply due to Type II errors. Power analyses revealed that if survival in the forest and pneumatophore habitats differed from that in the channel by $66 \%$ (i.e. 2 of the 3 tethered fish were lost), we had an $88 \%(F=3.885$, ES (effect size $)=1.015$, $\lambda=15.447$ ) chance of detecting a significant effect; the actual difference between the channel and the pneumatophores, and between the channel and forest, was 4 and $2 \%$ respectively. Similarly, if survival in exclusion cages differed from the other treatments by $66 \%$, we had a $95 \%(F=3.885, \mathrm{ES}=1.157, \lambda=20.090)$ chance of detecting significant effects. The actual differences in survival between exclusion cages and cage controls, and exclusion cages and uncaged treatments were 8 and $18 \%$, respectively.

Table 5. Results of 2-factor randomised blocks analyses of variance comparing abundances and species richness of fish between microhabitats (forest and pneumatophore) and among sampling occasions (1 to 5) for pop and fyke nets separately. All data is $\log _{10}(x+1)$ transformed. Total $\mathrm{n}=20$. Bold indicates $\mathrm{p}<0.05$

\begin{tabular}{|c|c|c|c|c|c|c|c|c|c|}
\hline \multirow[b]{3}{*}{ Source } & \multirow[b]{3}{*}{$\mathrm{df}$} & \multicolumn{4}{|c|}{-Abundance } & \multicolumn{4}{|c|}{-Species richness } \\
\hline & & \multicolumn{2}{|c|}{ Pop } & \multicolumn{2}{|c|}{ Fyke } & \multicolumn{2}{|c|}{ Pop } & & \multirow{2}{*}{$\begin{array}{l}\text { Fyke } \\
\mathrm{p}\end{array}$} \\
\hline & & MS & $\mathrm{p}$ & MS & $\mathrm{p}$ & $\mathrm{MS}$ & $\mathrm{p}$ & MS & \\
\hline Microhabitat & 1 & 0.081 & 0.155 & 1.939 & 0.096 & 0.00216 & 0.022 & 0.034 & 0.175 \\
\hline Occasion & 4 & 0.017 & 0.665 & 0.378 & 0.532 & $<0.0003$ & 0.223 & 0.011 & 0.554 \\
\hline Error & 4 & 0.026 & & 0.411 & & $<0.0001$ & & 0.013 & \\
\hline
\end{tabular}


Table 6. Results of a 3-factor randomised blocks analysis of variance comparing survival of tethered fish $(n=135)$ across microhabitats (forest, pneumatophore, and channel), cage treatments (exclusion cage, cage control, and uncaged) and sampling occasions (1 to 5). Data are arcsine-transformed. Total $\mathrm{n}=45$

\begin{tabular}{|lccc|}
\hline Source & df & MS & $p$ \\
\hline Cage (C) & 2 & 0.025 & 0.771 \\
Microhabitat (M) & 2 & 0.274 & 0.158 \\
Occasion (O) & 4 & 0.544 & 0.096 \\
M $\times$ C & 4 & 0.114 & 0.739 \\
$\mathrm{C} \times \mathrm{O}$ & 8 & 0.117 & 0.901 \\
$\mathrm{M} \times \mathrm{O}$ & 8 & 0.093 & 0.832 \\
Error & 16 & 0.230 & \\
\hline
\end{tabular}

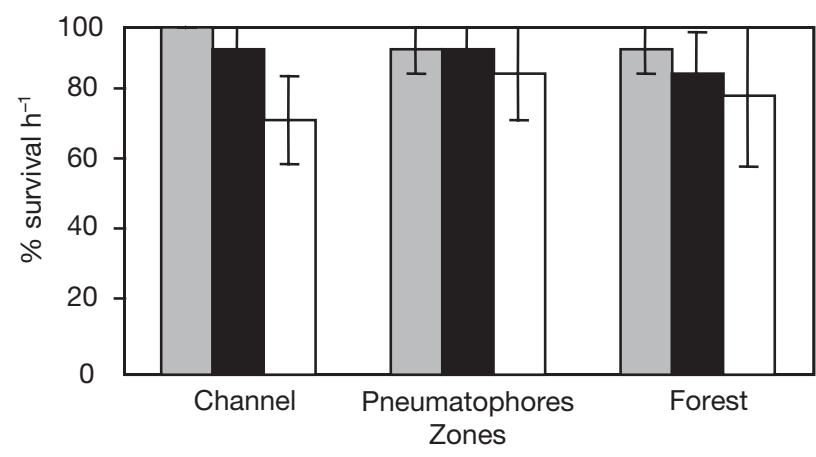

Fig. 7. Mean $( \pm \mathrm{SE}) \%$ survival $\left(\mathrm{h}^{-1}\right)$ of juvenile Aldrichetta forsteri tethered within predation treatments ( $\square$ exclusion cages, $\square$ cage controls, $\square$ uncaged). Total $\mathrm{n}=45$

\section{DISCUSSION}

\section{Interaction between microhabitat use of mangroves and diel period}

The greatest abundances, biomass and species richness of fish in the present study were found in the channel adjacent to the mangroves. Forests supported fewer species and much lower numbers of fish, but this pattern varied strongly depending on the time of day. During the day and night most fish were sampled in the channel, but at night fish abundances increased in the pneumatophores and forest. Movement of fish between microhabitats with diel periods may be due to changes in predation pressure (Gibson \& Robb 1996, Hindell et al. 2000). In the present study, larger predators such as Anguilla australis and Acanthopagrus butcheri were found in all microhabitats at night but were largely absent during the day. Larger Arripis truttacea were also more common at night in the channel and pneumatophores. These movements of predatory fish could maintain populations of smaller prey species, such as Aldrichetta forsteri, in habitats (and at depths) such as the forest where predation pressure is likely to be minimised (Gibson \& Robb 1996).

Alternatively, patterns in microhabitat use could be a function of depth variability. Mangrove studies have traditionally compared fish abundances using mangroves and adjacent habitats without attempting to address the influence of water depth (Robertson \& Duke 1987, Nagelkerken et al. 2000b). Meager et al. (2003), however, suggest that some epibenthic nekton (e.g. Acetes sibogae) may be significantly correlated with water depth depending on the microhabitat. In our study, species richness varied little with water depth regardless of microhabitat. Species abundances also varied negatively (but not significantly) with water depth in the channel, but were positively related to water depth in the pneumatophores and forest. While there was some cross-over in water depths between day and night, the average water depth was actually greater at night than during the day. The interaction, therefore, in fish abundances between times of the day and among microhabitats could actually reflect differences in water depth rather than diel period per se. The mechanisms underlying diel changes in microhabitat use are purely speculative, but our observations highlight the need for spatially explicit approaches to assessing use of mangroves, with emphasis on separating effects of diel regimes and water depth.

The results from studies using a single gear type to sample mangrove fishes may be restricted in their generality because of gear selectivity (Rozas \& Minello 1997, Sheaves 2001). We attempted to reduce the degree to which differential gear selectivity influenced among-microhabitat patterns in fish assemblage structure by using multiple gear types (fyke, gill and pop nets). While patterns of increasing fish abundance and species richness from the forest to the channel can be interpreted as microhabitat 'selection', it is also possible that patterns could at least be partially attributed to differential gear selectivity among microhabitats. Lower fish abundance in the forest than in the channel, for example, could be attributed to reduced gear effectiveness in the more complex forest structure. Since our study was done in 1 region over a course of several months, we must interpret the patterns cautiously. We suggest however, that differential gear effectiveness due to variable structure was not the primary cause of differences in fish assemblages across microhabitats for 3 reasons. First, fyke and gill nets (passive gear) are favoured over alternative towed nets, such as trawls and seines, in habitats with high levels of structure (e.g. mangrove forests) because their effectiveness depends more on fish movement and less on the ability to manoeuvre the net through the structure in order to trap fish. Enclosure devices such as pop nets have even 
fewer variables influencing catch efficiency, which is not thought to vary substantially with the presence of structure (Rozas \& Minello 1997). Second, while there were some differences in the species of fish sampled by the different types of gear, the overall patterns of fewer fish in the forest than pneumatophores (Surveys 1 and 2), and fewer fish in the pneumatophores than channel (Survey 1), although not always statistically significant, were consistent between gear types. Third, the water in our system was often highly turbid. This greatly reduced the visibility, and given that more fish were sampled in the channel during the day than night overall, suggests that fish may not have displayed significant gear avoidance.

Tropical mangroves are thought to support higher abundances and species diversity of fishes than temperate systems (Clynick \& Chapman 2002, Hindell \& Jenkins 2004). However, differences in sampling methodologies often prevent informative comparisons across studies in estuarine systems (Rozas \& Minello 1997, Connolly 1999), thereby masking broad-scale generality in findings. The present study is unique in that parallel work has been done elsewhere in subtropical and temperate Australia using similar (and in some cases the same) types of gear. G. Skilleter \& N. Loneragan (unpubl.) sampled >16000 fish from 47 species in a single summer using the same fyke nets we used here; their mean catches of juvenile and small fish (adjusted for fishing time) sometimes exceeded 700 fish $\mathrm{h}^{-1}$. In the present study, we sampled just 1954 individuals from 23 species in total (all gear types combined), with a maximum rate of cap-

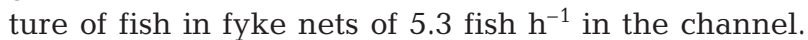
Although we ran only 10 trials with the pop nets, assemblages of fish sampled with this gear were also less rich than those reported in studies using highly quantitative methods in the tropics. Total densities of fish in our forest $\left(0.18\right.$ fish $\left.\mathrm{m}^{-2}\right)$ and pneumatophore (0.86 fish $\mathrm{m}^{-2}$ ) microhabitats were lower than those of Barletta et al. (2000), 2.8 fish $\mathrm{m}^{-2}$, Vance et al. (1996), 1.0 fish $\mathrm{m}^{-2}$ inside the forest, and Ronnback et al. (1999), 5.1 fish $\mathrm{m}^{-2}$ inside the forest. Conversely, a recent study by Hindell \& Jenkins (2005) in a separate temperate Australian mangrove system recorded mean fish densities of 2.0 fish $\mathrm{m}^{-2}$ in the forest, and 1.4 fish $\mathrm{m}^{-2}$ in the pneumatophores; values that are comparable (and in some cases exceed) those from the tropics. Species richness measured with the pop nets was also considerably lower in the present study, 2 and $8 \mathrm{spp}$. in the forest and pneumatophores, respectively, compared with Vance et al. (1996), 26 spp. along the creek/mangrove interface, Ronnback et al. (1999), 37 spp., and Barletta et al. (2000), 14 spp. The present study is consistent with previous work showing relatively low species richness in tem- perate systems (Clynick \& Chapman 2002, Hindell \& Jenkins 2004), but it is the first study to show that fish densities can also be significantly lower than those in tropical and subtropical mangroves.

\section{Predation not a driver of microhabitat use by fish in temperate mangroves}

Small and juvenile fish may use the interior of mangrove forests as a refuge from predation (Vance et al. 1996, Ronnback et al. 1999). The pattern of lower fish abundances, particularly small prey species such as Galaxias maculatus, Favonigobius tamarensis and Atherinasoma microstoma, inside forests and along the edge or channel in the present study was consistent with avoidance of shallow water and/or greater predation, despite the potential of increased structure mediating predation effects in these microhabitats. In contrast to this model, our tethering experiments showed that rates of predation on juvenile Aldrichetta forsteri were low across all microhabitats. This suggests that predation was not important in determining patterns of fish use across microhabitats, at least during the day when we would expect to see the greatest predation by birds and highly visual predatory fishes such as Arripis truttacea. In the absence of any predation effect, we suggest that the lower numbers of fish inside mangroves may be attributed to a lack of food, which in turn fits with models that suggest lower productivity in temperate mangroves (Alongi 2002). In order to better assess the contribution of varying food supply on fish use of microhabitats within temperate mangroves more attention should be given to assessing changes in the distribution of invertebrate prey across those microhabitats.

Problems associated with tethering experiments, such as restricting escape behaviour and entanglement of tethers are well documented (Haywood et al. 2003). High survival of juvenile Aldrichetta forsteri across structurally different microhabitats suggests that tangling and behavioural changes caused by tethering were unlikely to have influenced rates of predation. Tethering studies often overlook the need to control for the loss of tethered organisms and assume they have been eaten (Acosta \& Butler 1997, Haywood et al. 2003). Fish tethered in cages provide a useful means of testing the effectiveness of tethers by providing an estimate of the fish that have escaped their tethers without being eaten. For example, Laegdsgaard \& Johnson (2001) attributed greater predation to fishes on mudflats than seagrass or mangroves because tethered fish were not lost from predator exclusion cages. In our study, 2 fish were lost from closed cages, suggesting that fish had 'escaped' their tethers by means 
other than fish or bird predation. More fish were lost from uncaged and cage control treatments than exclusion cages, but the 2 losses from exclusion cages suggest that fish may have been removed from their tethers by invertebrate predators. Several species of grapsid crab are common in our study system and possibly prey on fish with restricted mobility. The results from our tethering study are not consistent with decreasing predation pressure by fish and birds with increasing structure of microhabitats within mangroves, and tethering studies in association with predator cages appear to be useful in elucidating non-target predation events.

\section{Nursery value of temperate mangroves}

Mangroves are widely cited as important nursery habitat for juvenile fish and crustaceans (Kathiresan \& Bingham 2001), but there is growing uncertainty as to whether mangroves actually support larger numbers and facilitate the survival of post-settlement nekton (Sheridan \& Hays 2003). The present study suggests that areas within mangroves support few small and juvenile fish compared with areas along the mangrove edge and in the channel. This pattern changes slightly during the night when more smaller fish appear to be using the pneumatophore and forest microhabitats. The greater abundances of larger fish in these microhabitats during the night present some interesting possibilities for assessing changes in the refuge value of (and resource use in) habitats with diel periods. The view that mangrove structure provides smaller fish and invertebrates with a refuge from predation (Primavera 1997, Laegdsgaard \& Johnson 2001) is also not supported here; the survival of fish did not vary across microhabitats. Based on the weak patterns of association with, and lack of, predation effect in mangroves observed here, the mangrove microhabitats in our study system do not appear to be differentially important as habitat for juvenile and small fishes.

Acknowledgements. This research was only possible because of generous funding from the Fisheries Research and Development Corporation (FRDC) and Fisheries Victoria. R. Watson, J. Smith, D. Rampal and D. King helped with field work. D. Ball helped with the preparation of figures. This research was done using the facilities at Marine and Freshwater Systems, PIRVic and the Victorian Marine Science Consortium.

\section{LITERATURE CITED}

Acosta AR, Appeldoorn RS (1995) Catching efficiency and selectivity of gillnets and trammel nets in coral reefs from southwestern Puerto-Rico. Fish Res 22:175-196
Acosta CA, Butler MJ (1997) Role of mangrove habitat as a nursery for juvenile spiny lobster, Panulirus argus, in Belize. Mar Freshw Res 48:721-727

Alevizon W, Richardson R, Pitts P, Serviss G (1985) Coral zonation and patterns of community structure in Bahamian reef fishes. Bull Mar Sci 36:304-318

Alongi D (2002) Present state and future of the world's mangrove forests. Environ Conserv 29:331-349

Aronson RB, Keck KL, Valentine JF (2001) Measuring predation with tethering experiments. Mar Ecol Prog Ser 214: 311-312

Barletta M, Saint-Paul U, Barletta-Bergan A, Werner E, Schories D (2000) Spatial and temporal distribution of Myrophis punctatus (Ophichthidae) and associated fish fauna in a northern Brazilian intertidal mangrove forest. Hydrobiologia 426:65-74

Bell JD, Pollard DA, Burchmore JJ, Pease BC, Middleton MJ (1984) Structure of a fish community in a temperature tidal mangrove creek in Botany Bay, New South Wales. Aust J Mar Freshw Res 35:33-46

Chong VC, Sasekumar A, Leh MUC, D'Cruz R (1990) The fish and prawn communities of a Malaysian coastal mangrove system, with comparisons to adjacent mud flats and inshore waters. Estuar Coast Shelf Sci 31:703-722

Clarke KR, Warwick RM (2001) Changes in marine communities: an approach to statistical analysis and interpretation, 2nd edn. Primer-E, Plymouth

Clarke PJ (2004) Effects of experimental canopy gaps on mangrove recruitment: lack of habitat partitioning may explain stand dominance. J Ecol 92:203-213

Clynick B, Chapman M (2002) Assemblages of small fish in patchy mangrove forests in Sydney Harbour. Mar Freshw Res 53:669-677

Connolly RM (1994) Comparison of fish catches from a buoyant pop net and a beach seine in a shallow seagrass habitat. Mar Ecol Prog Ser 109:305-309

Connolly RM (1999) Saltmarsh as habitat for fish and nektonic crustaceans: challenges in sampling designs and methods. Aust J Ecol 24:422-430

Dahdouh-Guebas F, Verneirt M, Cannicci S, Kairo J, Tack J, Koedam N (2002) An exploratory study of grapsid crab zonation in Kenyan mangroves. Wetlands Ecol Manage 10:179-187

Edgar GJ, Shaw C (1995) The production and trophic ecology of shallow-water fish assemblages in southern Australia. II. Diets of fishes and trophic relationships between fishes and benthos at Western Port, Victoria. J Exp Mar Biol Ecol 194:83-106

Faul F, Erdfelder E (1992) GPOWER: a priori, post-hoc, and compromise power analyses for MS-DOS. Dept of Psychology, Bonn University, Bonn

Gibson RN, Robb L (1996) Piscine predation on juvenile fishes on a Scottish sandy beach. J Fish Biol 49:120-128

Gibson RN, Pihl L, Burrows MT, Modin J, Wennhage $H_{\text {, }}$ Nickell LA (1998) Diel movements of juvenile plaice Pleuronectes platessa in relation to predators, competitors, food availability and abiotic factors on a microtidal nursery ground. Mar Ecol Prog Ser 165:145-159

Gomon MF, Glover JCM, Kuiter RH (1994) The Fishes of Australia's south coast. State Print, Adelaide

Gray CA (2002) Management implications of discarding in an estuarine multi-species gill net fishery. Fish Res 56: $177-192$

Harty C (1997) Mangroves in NSW and Victoria: forests of the tidal zone in temperate Australia. Vista Publications, Melbourne

Haywood MDE, Manson FJ, Loneragan NR, Toscas PJ (2003) 
Investigation of artifacts from chronographic tethering experiments - interactions between tethers and predators. J Exp Mar Biol Ecol 290:171-292

Hindell J, Jenkins G (2004) Spatial and temporal variability in the assemblage structure of fishes associated with mangroves (Avicennia marina) and intertidal mudflats in temperate Australian embayments. Mar Biol 144:385-396

Hindell J, Jenkins G (2005) Assessing patterns of fish zonation in temperate mangroves, with emphasis on evaluating sampling artifacts. Mar Ecol Prog Ser 290:193-205

Hindell JS, Jenkins GP, Keough MJ (2000) Variability in abundances of fishes associated with seagrass habitats in relation to diets of predatory fishes. Mar Biol 136: 725-737

Hindell J, Jenkins G, Keough M (2001) Spatial and temporal variability in the effects of predation on macrofauna in relation to habitat complexity and cage effects. Mar Ecol Prog Ser 224:231-250

Jenkins GP, Black KP (1994) Temporal variability in settlement of a coastal fish (Sillaginodes punctata) determined by low-frequency hydrodynamics. Limnol Oceanogr 39(7): 1744-1754

Jernakoff P, Brearley A, Nielsen J (1996) Factors affecting grazer-epiphyte interactions in temperate seagrass meadows. Oceanogr Mar Biol Annu Rev 34:109-162

Kailola PJ, Williams MJ, Stewart PC, Reichelt RE, McNee A, Grieve C (1993) Australian fisheries resources. Bureau of Resource Sciences, Department of Primary Industries and Energy, and Fisheries Research and Development Corporation, Canberra

Kathiresan K, Bingham B (2001) Biology of mangroves and mangrove ecosystems. Adv Mar Biol 40:84-136

Laegdsgaard P, Johnson CR (1995) Mangrove habitats as nurseries: unique assemblages of juvenile fish in subtropical mangroves in eastern Australia. Mar Ecol Prog Ser 126:67-81

Laegdsgaard P, Johnson C (2001) Why do juvenile fish utilise mangrove habitats? J Exp Mar Biol Ecol 257:229-253

Laroche J, Baran E, Rasoanandrasana N (1997) Temporal patterns in a fish assemblage of a semiarid mangrove zone in Madagascar. J Fish Biol 51:3-20

Ley JA, McIvor CC, Montague CL (1999). Fishes in mangrove prop root habitats of northeastern Florida Bay: distinct assemblages across an estuarine gradient. Estuar Coast Shelf Sci 48:710-723

Lin HJ, Shao KT (1999) Seasonal and diel changes in a subtropical mangrove fish assemblage. Bull Mar Sci 65: $775-794$

Lorenz J (1999) The response of fishes to physicochemical changes in the mangroves of northeast Florida Bay. Estuaries 22:500-517

Meager J, Vance D, Williamson I, Loneragan N (2003) Microhabitat distribution of juvenile Penaeus merguiensis de Man and other epibenthic crustaceans within a mangrove forest in subtropical Australia. J Exp Mar Biol Ecol 294: $127-144$

Morton RM (1990) Community structure, density and standing crop of fishes in a subtropical Australian mangrove area. Mar Biol 105:385-394

Nagelkerken I, Dorenbosch $M$, Verberk WCEP, de la Moriniere EC, van der Velde G (2000a) Day-night shifts of fishes between shallow-water biotopes of a Caribbean bay, with emphasis on the nocturnal feeding of Haemulidae and Lutjanidae. Mar Ecol Prog Ser 194:55-64

Nagelkerken I, Van der Velde G, Gorissen M, Meijer G, Van't Hof T, Den Hartog C (2000b) Importance of mangroves, seagrass beds and the shallow coral reef as a nursery for important coral reef fishes, using a visual census technique. Estuar Coast Shelf Sci 51:31-44

Nagelkerken I, Kleijnen S, Klop T, van den Brand RACJ, Cocheret de la Moriniere E, van der Velde G (2001) Dependence of Caribbean reef fish on mangroves and seagrass beds as nursery habitats: a comparison of fish faunas between bays with and without mangroves/ seagrass beds. Mar Ecol Prog Ser 214:225-235

OZESTUARIES (2000) Estuary assessment 2000. National Land \& Water Resources Audit: a program of the Natural Heritage Trust. www.ozestuaries.org

Peterson BJ, Thompson KR, Cowan JH, Heck Jnr KL (2001) Comparison of predation pressure in temperate and subtropical seagrass habitats based on chronographic tethering. Mar Ecol Prog Ser 224:77-85

Pinto L (1987) Environmental factors influencing the occurrence of juvenile fish in the mangroves of Pagbilao, Philippines. Hydrobiologia 150:283-301

Primavera J (1997) Fish predation on mangrove-associated penaeids: the role of structures and substrate. J Exp Mar Biol Ecol 215:205-216

Quinn G, Keough M (2002) Experimental design and data analysis for biologists. Cambridge University Press, Cambridge

Robertson AI (1982) Population dynamics and feeding ecology of juvenile Australian Salmon (Arripis trutta) in Western Port, Victoria. Aust J Mar Freshw Res 33:369-375

Robertson AI, Duke NC (1987) Mangroves as nursery sites: comparisons of the abundance and species composition of fish and crustaceans in mangroves and other nearshore habitats in tropical Australia. Mar Biol 96:193-205

Ronnback P, Troell M, Kautsky N, Primavera JH (1999) Distribution pattern of shrimps and fish among Avicennia and Rhizophora microhabitats in the Pagbilao Mangroves, Philippines. Estuar Coast Shelf Sci 48:223-234

Ronnback P, Macia A, Almqvist G, Schultz L, Troell M (2002) Do penaeid shrimps have a preference for mangrove habitats? Distribution pattern analysis on Inhaca Island, Mozambique. Estuar Coast Shelf Sci 55:427-436

Rooker JR, Dennis GD (1991) Diel, lunar and seasonal changes in a mangrove fish assemblage off southwestern Puerto Rico. Bull Mar Sci 49:684-698

Rozas LP (1992) Bottomless lift net for quantitatively sampling nekton on intertidal marshes. Mar Ecol Prog Ser 89: $287-292$

Rozas LP, Minello TJ (1997) Estimating densities of small fishes and decapod crustaceans in shallow estuarine habitats: a review of sampling design with focus on gear selection. Estuaries 20:199-213

Satumanatpan S, Keough MJ (2001) Role of larval supply and behaviour in determining settlement of barnacles in a temperate mangrove forest. J Exp Mar Biol Ecol 260: 133-153

Satumanatpan S, Keough MJ, Watson GF (1999) Role of settlement in determining the distribution and abundance of barnacles in a temperate mangrove forest. J Exp Mar Biol Ecol 241:45-66

Sheaves M (2001) Are there really few piscivorous fishes in shallow estuarine habitats? Mar Ecol Prog Ser 222: 279-290

Sheridan P, Hays C (2003) Are mangroves nursery habitat for transient fishes and decapods. Wetlands 23:449-458

Thayer GW, Colby DR, Hettler WF (1987) Utilization of the red mangrove prop root habitat by fishes in south Florida. Mar Ecol Prog Ser 35:25-38

Underwood AJ, Chapman MG (1995) Mangrove forests. In: Underwood AJ, Chapman MG (eds) Coastal marine eco- 
logy of temperate Australia. University of New South Wales Press, Sydney, p 187-204

Vance D, Haywood M, Heales D, Kenyon R, Loneragan N, Pendrey R (2002) Distribution of juvenile penaeid prawns in mangrove forests in a tropical Australian estuary, with particular reference to Penaeus merguiensis. Mar Ecol Prog Ser 228:165-177

Vance DJ, Haywood MDE, Heales DS, Kenyon RA, Lonera-

Editorial responsibility: Otto Kinne (Editor-in-Chief), Oldendorf/Luhe, Germany gan NR, Pendrey RC (1996) How far do prawns and fish move into mangroves? Distribution of juvenile banana prawns Penaeus merguiensis and fish in a tropical mangrove forest in northern Australia. Mar Ecol Prog Ser 131: $115-124$

Wilkinson L, Hill M, Welna JP, Birkenbeuel GK (1992) SYSTAT for Windows: Statistics, Version 5 edition. SYSTAT, Evanston, IL

Submitted: August 4, 2004; Accepted: January 11, 2005 Proofs received from author(s): May 13, 2005 